\title{
Amazing Grazing: A Public and Private Partnership to Stimulate Grazing Practices in Intensive Dairy Systems
}

\author{
René Schils ${ }^{1, *(\mathbb{D}, \text { Bert Philipsen }}{ }^{2}$, Nyncke Hoekstra ${ }^{3}$, Gertjan Holshof ${ }^{2}$, Ronald Zom ${ }^{2}$, \\ Idse Hoving ${ }^{4}$, Kees van Reenen ${ }^{5}$, Marcia Stienezen ${ }^{2}$, Cindy Klootwijk ${ }^{2,6}$, Joop van der Werf ${ }^{5}$, \\ Léon Sebek ${ }^{2}$, Nick van Eekeren ${ }^{3}$, Ingrid van Dixhoorn ${ }^{5}$ and \\ Agnes van den Pol-van Dasselaar 2,7 \\ 1 Agrosystems Research, Wageningen Plant Research, 6708 PB Wageningen, The Netherlands \\ 2 Animal Nutrition, Wageningen Livestock Research, 6708 WD Wageningen, The Netherlands; \\ bert.philipsen@wur.nl (B.P.); gertjan.holshof@wur.nl (G.H.); ronald.zom@wur.nl (R.Z.); \\ marcia.stienezen@wur.nl (M.S.); cindy.klootwijk@wur.nl (C.K.); leon.sebek@wur.nl (L.S.); \\ a.van.den.pol@aeres.nl or agnes.vandenpol@wur.nl (A.v.d.P.-v.D.) \\ 3 Agriculture, Louis Bolk Institute, 3981 AJ Bunnik, The Netherlands; n.hoekstra@louisbolk.nl (N.H.); \\ n.vaneekeren@louisbolk.nl (N.v.E.) \\ 4 Livestock and Environment, Wageningen Livestock Research, 6708 WD Wageningen, The Netherlands; \\ idse.hoving@wur.nl \\ 5 Animal Health \& Welfare, Wageningen Livestock Research, 6708 WD Wageningen, The Netherlands; \\ kees.vanreenen@wur.nl (K.v.R.); joop.vanderwerf@wur.nl (J.v.d.W.); ingrid.vandixhoorn@wur.nl (I.v.D.) \\ 6 Animal Production Systems, Wageningen University, 6708 WD Wageningen, The Netherlands \\ 7 Department Grassland and Grazing, Aeres University of Applied Sciences, \\ 8251 JZ Dronten, The Netherlands \\ * Correspondence: rene.schils@wur.nl; Tel.: +31-317-484743
}

Received: 28 August 2019; Accepted: 17 October 2019; Published: 22 October 2019

\begin{abstract}
In many intensive dairy regions in northwest Europe, a decline in grazing is observed. In the Netherlands, the proportion of dairy cows with access to pasture is declining, as well as the time spent grazing per cow. The decline in grazing is seen as an unwanted trend by many stakeholders and is, thus, under debate amongst dairy farmers, the dairy chain, and society. Therefore, a public-private partnership was initiated to encourage grazing by providing farmers with usable means of improving their grazing systems. The partnership involved stakeholders from the dairy farming community, dairy and feed industry, agrotechnical industries, advisory services, and research. The objective of this partnership was to develop and stimulate technological innovations and management measures that increase fresh grass intake at pasture. The innovation network combined an integrated research approach with farmer working groups and broader stakeholder interactive meetings. The project started with a comprehensive grass intake framework, which was the foundation for exploration of innovations. The framework consisted of six interlinked components: soil, grass growth, grass supply, grass intake, feed supplementation, and cow behavior. In a continuous interactive cycle, strategic choices were made to focus on potentially effective innovations. The use of a public-private partnership to develop usable innovations that encourage grazing practices proven to be a good approach to develop a shared vision among stakeholders. It provided a basis to work together toward innovative practices and to disseminate the outcomes to the foreseen users. The approach succeeded in design concepts for two specific innovations, i.e., weekly grass growth predictions and daily fresh grass intake tracking. We demonstrated that meaningful grazing and fresh grass intake are possible in intensive dairy systems with high stocking rates and high levels of supplementary feeding.
\end{abstract}

Keywords: dairy sector; grassland; interdisciplinary research; stakeholders; agricultural innovation system 


\section{Introduction}

\subsection{Decline in Grazing}

Dairy production from grazed pastures is a familiar farming practice in Europe. A study in seven regions in northwestern Europe [1] showed that, in 2012, pasture access of dairy cows varied from nearly year-round almost unrestricted grazing, as seen all around Ireland, to year-round housing and no pasture access at all, which is the dominant system in Denmark. In between are many variations of restricted grazing systems, restricted either in daily access or in the length of the grazing season. Trend data about the proportion of grazing in Europe are sparse. Downward grazing trends are projected between 2012 and 2025 for five out of seven regions in northwestern Europe [1]. Expert estimates from the European Grassland Federation (EGF) grazing working group generally show a downward trend of the proportion of cows with access to pasture [2,3]. Data from the Netherlands $[4,5]$ showed that the proportion of cows that were housed year-round increased from around $10 \%$ at the end of the previous century to around $30 \%$ in recent years (Figure 1). Furthermore, there was a clear shift from unrestricted to restricted grazing. Additionally, the proportion of young stock that had access to pasture showed a steady decline as well. In Flanders, within the $20 \%$ most productive dairy farms, the intake of fresh grass was reduced from 7.0 to $3.6 \mathrm{~kg}$ dry matter $(\mathrm{DM}) \cdot \mathrm{cow}^{-1} \cdot \mathrm{day}^{-1}$ between 2003/2004 and 2013/2014 [6].

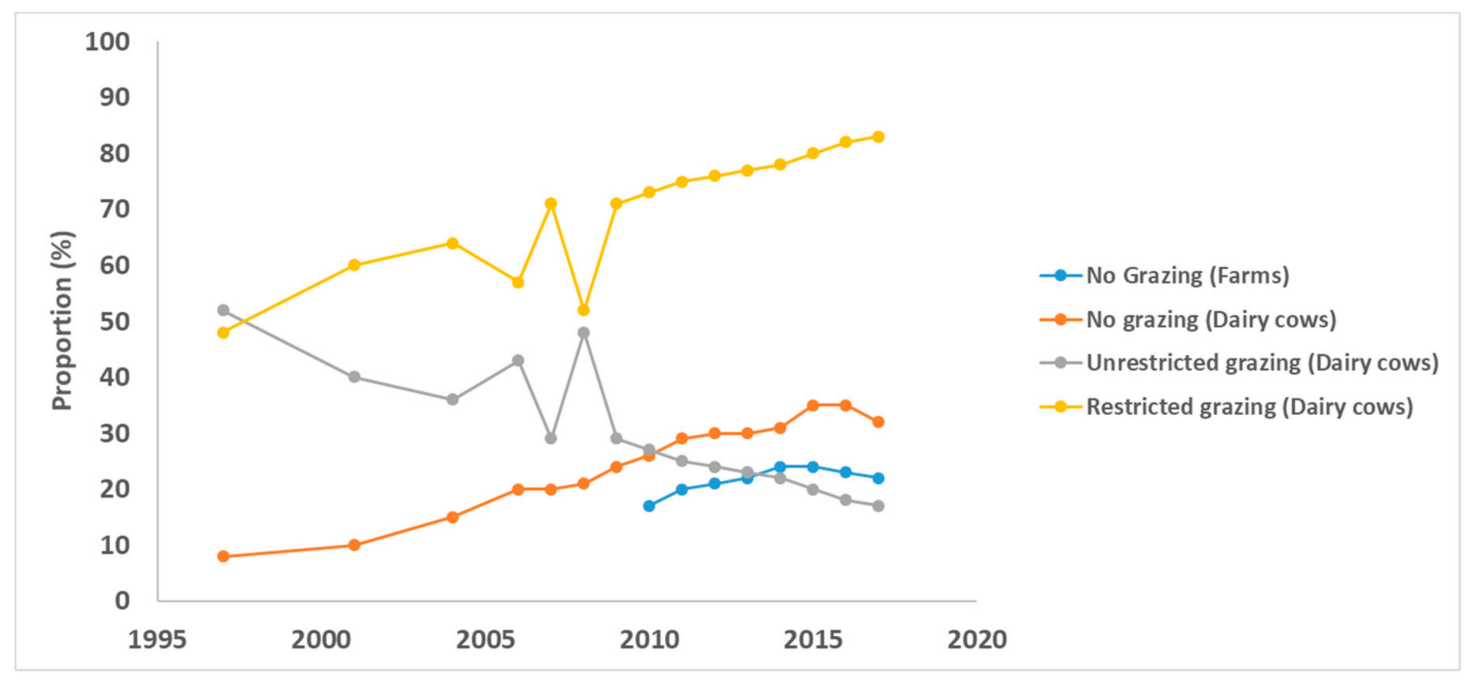

Figure 1. Trends in grazing in Netherlands; proportion of dairy cows or farms in different grazing systems $[4,5]$.

\subsection{Motivation for and against Grazing}

The main drivers for reduced grazing are increased farm and herd size, increased use of automatic milking systems, competition for other land use like arable crops or settlements, poor spatial farm layout prohibiting pasture access for animals, and reduced knowledge and skills of farmers, and their advisers, in designing and managing grazing systems [7]. More specifically, increased herd sizes combined with a lack of increase in the available grazing area lead to an increase in the stocking rate on the available grazing area, which reduces the potential for grazing. Even when land is added to the grazing area, walking distances to the milking parlor or automatic milking system may be a limiting factor.

Grazing cows, however, have a positive image and contribute to societal acceptance of dairy farming and dairy products [8]. A survey in Germany showed that public acceptance of dairy farming 
housing systems clearly increased with the presence of a paddock or pasture [9]. Stakeholders appreciate grazing livestock for their contribution to cultural ecosystem services, e.g., cultural, historic, and natural heritage, as well as educational, landscape, and recreational values, and for supporting and regulating ecosystem services, e.g., habitat provision, nutrient cycling, climate, and flood control [10]. In addition, grazing is also suggested to benefit animal health and behavior [11,12]. It was found [13] that cows were highly motivated to overcome a physical barrier (in this case, a weighted gate to be pushed) to spend time at pasture. Hunger was not the main driver, but rather the motivation to be outside and to express behavior associated with outdoor access. Several studies showed that pasture-based dairy farming has a lower environmental impact than confinement systems due to lower resource use and lower emissions of pollutants and greenhouse gases [14-16]. Furthermore, grazing dairy cows at pasture may also affect the composition, and processing and sensory properties of dairy products [17-19]. Milk from grazing cows contains higher proportions of unsaturated fatty acids and conjugated linoleic acids (CLAs) [19]. An exhaustive review [20] indicated that CLAs from ruminant animal food products (milk and meat) may have efficacy against cancer, obesity, and atherosclerosis in animal models. However, more research is needed to validate the effect of CLAs in pre-clinical and human trials.

Gross grassland production and net grass intake per ha are lower under grazing management due to the relatively fast defoliation rhythm and grazing losses around manure patches and trampled areas, especially in unrestricted grazing systems. Grazing systems have a lower forage use efficiency, i.e., forage harvested or consumed divided by potential forage production, than systems based on preserved forage [21]. Forage use efficiency increases by exercising more control over the animal's intake behavior. Pasture-based rations, without any supplementation, provide net energy to meet the requirements of maintenance and 21 to $24 \mathrm{~kg}$ of energy corrected milk [22]. Supplementation with forage and concentrate promotes DM intake compared to grazing only and allows the farmer to optimize nutrient intake and to balance fluctuations in the availability and feeding value of pasture [23]. At the same intensity, confined systems have a higher nitrogen utilization than grazing systems. The spatial and temporal variability of feces and urine deposition increases the potential losses of nitrate, nitrous oxide, dinitrogen, and phosphates. Manure collected indoors can be used more efficiently by avoiding these losses, thus potentially saving on manufactured fertilizer inputs.

Overall, grazing is financially more attractive than confinement, as grazing cows harvest grass and return excreta themselves, saving the costs of mechanization. However, the variability is high, and low and high incomes are seen in both groups of grazing and non-grazing farms. In general, the financial benefit of grazing is highly related to fresh grass intake per cow [24]. Labor requirements are also generally lower on farms with grazing, even though the execution and planning of grazing may be time-consuming.

The decline of grazing is under debate amongst dairy farmers, the dairy chain, and society. Some Dutch dairy producers pay a premium on milk from farmers that graze their dairy cows for at least six hours a day for at least 120 days per year. In 2012, a treaty on grazing was initiated with the aim to stabilize the proportion of farms that practice grazing. More than 80 stakeholders in the Netherlands signed this treaty including dairy farmers, dairy producers, the feed industry, banks, accountants, the semen industry, veterinarians, cheese sellers, retail, non-governmental organizations (NGOs), nature conservation, government, education, and science.

A study in the Netherlands [25] concluded that grazing, defined as at least 120 days with six hours per day, remains possible on $85 \%$ of the dairy farms in the Netherlands. A crucial parameter that determines the ability to graze is the stocking rate per ha of available grazing pasture. Above a stocking rate of approximately six cows per ha, it becomes increasingly difficult to maintain six hours of grazing per day. Although the present stocking rate is lower than six cows $\cdot \mathrm{ha}^{-1}$ on the majority of farms, a continuation of the trend of increasing farm size will lead to an increasing proportion of farms with stocking rates of above six cows $\cdot h a^{-1}$ on the available grazing area. 


\subsection{Amazing Grazing}

Public and private sectors have a long history of co-operation in the Dutch agricultural research and knowledge system [26]. During the 20th century, a system was developed with shared costs for applied research in various farming sectors. The managing boards prioritized technical innovations and problems that affected the profitability of production systems. Research priorities were mainly based on the needs of the primary sectors and less on the wishes of other stakeholders in the food chain, such as the processing industry and consumers. Since then, it was recognized that solving the complex problems facing the agricultural sector is beyond the reach of a single actor alone [27]. Therefore, agricultural innovation policies are promoted in which stakeholders work together on innovation. Within the agricultural sector, in the Netherlands and beyond, public-private partnerships are popular examples of such collaborative efforts with the aim of providing added value for all stakeholders involved [28].

A public-private partnership, Amazing Grazing, was initiated to address the challenges that farmers face in implementing grazing at high stocking rates, and to provide them with usable means of improving their grazing systems. Amazing Grazing is embedded within the broader sectoral Dutch Agricultural Innovation System of Public-Private Partnerships [29]. Amazing Grazing was initiated by two research organizations and two dairy producers, and was financed by the Dutch dairy supply chain (DairyNL) and the Ministry of Agriculture, Nature, and Food Quality. The group of stakeholders was extended with individual dairy farmers and representatives of dairy farmer organizations, independent farm consultants and consultants from the primary supply chain (feed, seeds, and fertilizers), representatives from service suppliers (software and hardware), and policy-makers from governmental and non-governmental organizations. They were engaged in each phase of the project, but especially in the convergence steps, evaluating research outcomes and selecting promising measures and technologies for potential uptake. The goal of this innovation network was to develop and stimulate uptake of technological innovations and management measures that increase efficient grazing practices by farmers. By doing so, the partnership aims to contribute to preventing a further decline of grazing practices in the Netherlands and comparable intensive dairy regions in Europe and across the globe. The objective of the present paper is to describe and evaluate the approach of the Amazing Grazing public-private partnership, from an initial broad research agenda toward the selection of potentially effective innovations.

The paper is structured along two lines. The main storyline deals with the approach of Amazing Grazing as a public-private partnership. The secondary storyline elaborates on the actual research activities in Amazing Grazing, and presents brief descriptions of methods and results. The full experimental details of the secondary storyline are not part of this paper, as they are reported or are to be reported in detail in other publications.

\section{Methodology}

\subsection{Innovation Approach}

We adopted an innovation approach involving private and public actors, combining elements from the broad spectrum of innovation models, from relative straightforward technology transfer to co-innovation using multiple-participant processes and partnerships [30]. The selection and convergence from a wide range of technological options to a selection of new designs was carried out in a repetitive interactive cycle with stakeholders (Figure 2).

As a first step, the 2014-2019 "grass and grazing" research agenda [31], developed by Wageningen UR and stakeholders from the dairy sector, government, NGOs, and agri-business, was used to collect and develop various promising technological concepts related to grazing practices. This was carried out in meetings and workshops with the involved stakeholders. The first convergence concluded with six research questions that were compiled into a coherent framework. Each research question was addressed either in controlled experiments or in on-farm testing. The second convergence determined 
promising innovations from these tests that were further developed into concepts and prototypes to be used by dairy farmers.
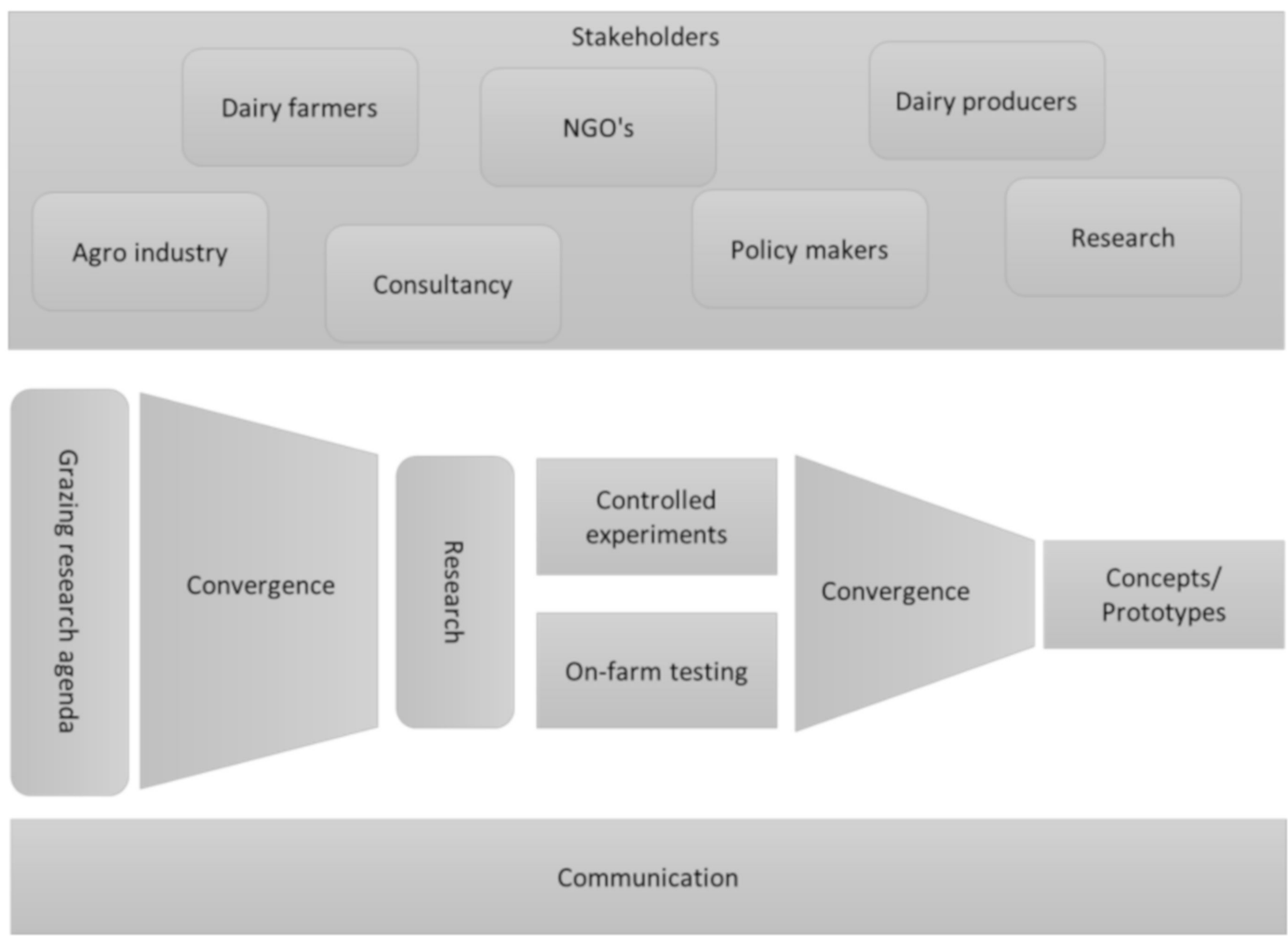

Figure 2. Work scheme of Amazing Grazing, showing convergence steps from a broad problem definition to a focus on potential innovations for uptake in practice. Adapted from Reference [32].

Information on proposed ideas, research set-up, intermediate outcomes, and final results were communicated continuously to all concerned and represented by the stakeholders. Communication was carried out in interviews, blogs, videos, newsletters, articles in farming press, an interactive e-book, peer-reviewed papers, and conference contributions.

\subsection{Research Framework}

In the first convergence step, we developed a comprehensive grass intake framework (Figure 3), which was the foundation for exploration of selected innovations. The first proposals for this framework were drafted by the initiators of the partnership, and were subsequently adapted by interaction with all stakeholders. The final framework consisted of six interlinked components: soil, grass growth, grass supply, grass intake, feed supplementation, and cow behavior. Below, we list, for each of the six components, a short description of the intended innovation, the associated research objective, and a brief description of the set-up. Where possible, different innovations were addressed in a single research set-up. The research activities comprised (1) two grazing experiments with contrasting grazing systems, (2) three cutting trials on clay, sand, and peat soil, and (3) three working groups with farmers, consultants, and researchers.

\subsubsection{Soil}

Innovation: Extending the length of the grazing season by improving sward density and carrying capacity on peat soil through kurzrasen (continuous grazing at 3-5-cm sward height).

Research aim: To study the effect of grazing system on sward density and soil bearing capacity.

Set-up: Grazing experiment on peat soil (Knowledge Transfer Centre Zegveld), comparing kurzrasen (continuous grazing at 3-5-cm sward height) and strip grazing (daily rotational grazing 
with 10-15-cm pre-grazing sward height). Sward density was measured 2-3 times a year with the point-quadrat method, and soil bearing capacity was measured five times a year with an analogous penetrometer. Details are presented in Reference [33].

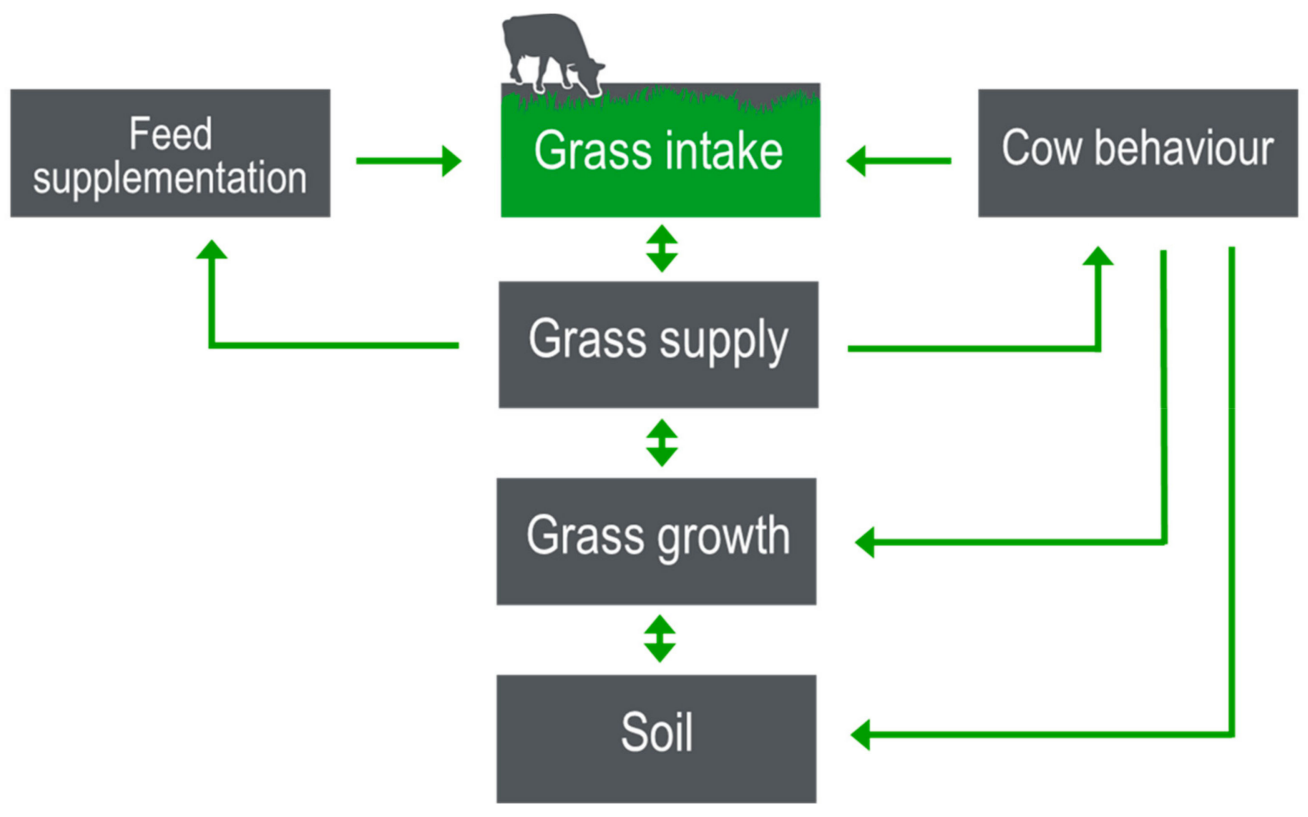

Figure 3. Framework of Amazing Grazing, consisting of six interlinked components around grazing.

\subsubsection{Grass Growth}

Innovation: Prediction of short-term grass growth to improve grassland planning.

Research aim: Validation of existing grass growth model [34].

Set-up: Cutting trials on clay, sand, and peat soil with a combination of nitrogen application rates and grass growth intervals. Short-term predictions of grass DM yield based on crop growth modeling and meteorological forecasts were compared to observed growth. Details are presented in Reference [35].

\subsubsection{Grass supply}

Innovation: Monitoring and using grassland management data to improve grass utilization.

Research aim: Development of dashboards to support and improve grassland planning and use.

Set-up: In an interactive setting, working groups of farmers, consultants, and researchers focused on developing planning rules and tools for either continuous grazing, rotational grazing, or cutting. Field specific data on sward heights were collected and tested in prototypes of grassland management dashboards. Details are presented in Reference [36].

\subsubsection{Grass Intake}

Innovation: Establish meaningful grass intakes, i.e., around or above $6 \mathrm{~kg} \mathrm{DM} \cdot \mathrm{cow}^{-1} \cdot \mathrm{day}^{-1}$ in farm systems with high stocking rates on the available grazing area.

Research aim: The effect of grazing system on grass production, grass intake, and milk production in farm systems with high stocking rates.

Set-up: Two experiments with contrasting grazing systems. The first location was a peat soil (KTC Zegveld), comparing kurzrasen and strip grazing. The second location was a clay soil (Dairy Campus, Leeuwarden), comparing strip grazing and compartmented continuous grazing (an adapted continuous grazing system in which the cows rotate on a daily basis between six compartments in one paddock, with target swards heights of around $8 \mathrm{~cm}$ ). The stocking rate was 7.5 cows $\cdot \mathrm{ha}^{-1}$ for all systems and locations. Details are presented in References [33,37]. 


\subsubsection{Feed Supplementation}

Innovation: Low protein contents in supplemented concentrates to stimulate fresh grass intake at pasture.

Research aim: Effect of rumen degradable protein balance in concentrates on fresh grass intake at pasture.

Set-up: The level of rumen degradable protein balance was introduced as a subfactor in the grazing experiment at Dairy Campus. The contrast was created by supplementing concentrates differing in rumen degradable protein balance. Each year, there were three measurement periods of a week, in which grass intake at pasture was estimated with the alkane marker technique. Details are presented in Reference [38].

\subsubsection{Cow Behavior}

Innovation: Using cow sensor data to improve fresh grass intake estimates and, thus, support grazing and feeding management decisions of dairy farmers.

Research aim: Development and calibration of a predictive model for daily grass intake for individual cows at pasture, using cow sensor data.

Set-up: All cows in the grazing experiment at Dairy Campus were equipped with leg, neck, and ear sensors that recorded the number of steps, as well as eating and ruminating time. Cow sensor data during the measurement periods, in which grass intake at pasture was estimated with the alkane marker technique, were used to calibrate a grass intake model. Details are presented in Reference [39].

\subsection{Evaluation and Prototyping}

In the second convergence step, the outcomes of the research phase were evaluated in stakeholder meetings. These meetings already started in the first research year and discussed preliminary outcomes. They were repeated every six months. The purpose of the second convergence step was to select promising innovations that could be further developed into prototypes for farm testing. The aim of Amazing Grazing was to develop and stimulate uptake of technological innovations and management measures that increase the uptake of grazing practices by farmers. It was foreseen that innovation concepts needed to be taken up by agri-business for further development in marketable products. Each innovation was evaluated on effectivity, farmer needs, innovative value, practicality, and implementation potential. For these meetings, around 30 persons representing all stakeholders were invited. The general set-up consisted of several rounds: plenary presentation of research outcomes, discussing outcomes and assessment of all innovations, and prioritizing the next development steps by individual scoring of each participant.

The selected innovations were translated into design concepts and, when possible, prototypes were developed and tested in a farm setting. During the prototyping phase, stakeholder meetings continued with the same frequency, monitoring and evaluating all intermediate steps, and re-directing when necessary.

\section{Results}

\subsection{Research Outcomes}

\subsubsection{Soil}

The load bearing capacity ranged from around 0.4 to $2.0 \mathrm{MPa}$. The load bearing capacity tended to be higher for kurzrasen than for strip grazing, but significant $(p<0.05)$ differences were only observed in two out of the 10 measurement campaigns. The average sward density cover was around 0.8 and 0.6 for kurzrasen and strip grazing, respectively. Significant $(P<0.05)$ differences were observed in four out of the five measurement campaigns. The load bearing capacity was generally positively correlated with the sward density (Figure 4), significantly so during July 2016 and July and October 2017. 


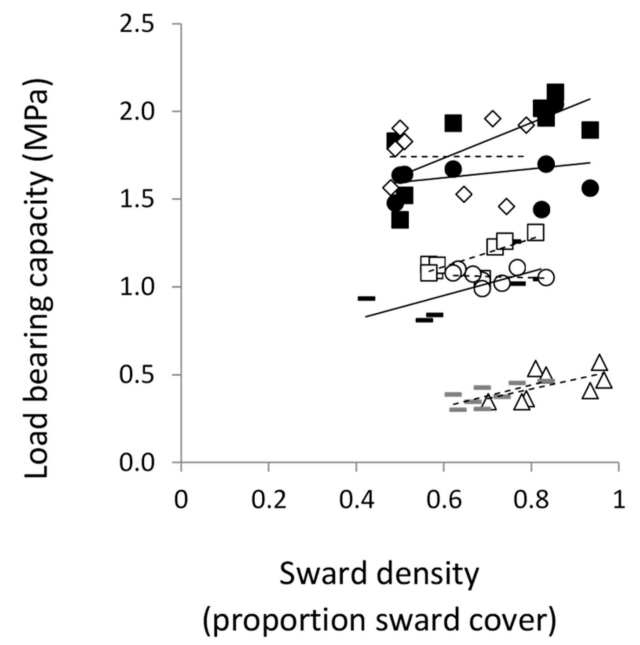

Figure 4. Relationship between load bearing capacity and sward density for kurzrasen and strip grazing in 2016 and 2017 during March/April $\mathbf{\Lambda}$, May $\bullet$, July $\mathbf{\square}$, September •, and October/November Adapted from Reference [33].

\subsubsection{Grass Growth}

The observed yields were used to validate the grass growth model, using the actual observed weather data. The prediction accuracy of grass growth varied between years, locations, and cuts (Figure 5). In general, predictions were better on mineral soils than on peat soils. The percentage of variation accounted for $\left(R^{2}\right)$ of the log transformed yields was $71 \%$ for clay, $74 \%$ for sand, and $68 \%$ for peat. The prediction accuracy was affected by mismatches in the actual and assumed soil nitrogen supply. Furthermore, it appeared that the available soil moisture model, developed for sandy soil, was not able to simulate the more complex hydrological situations on clay and peat soils.

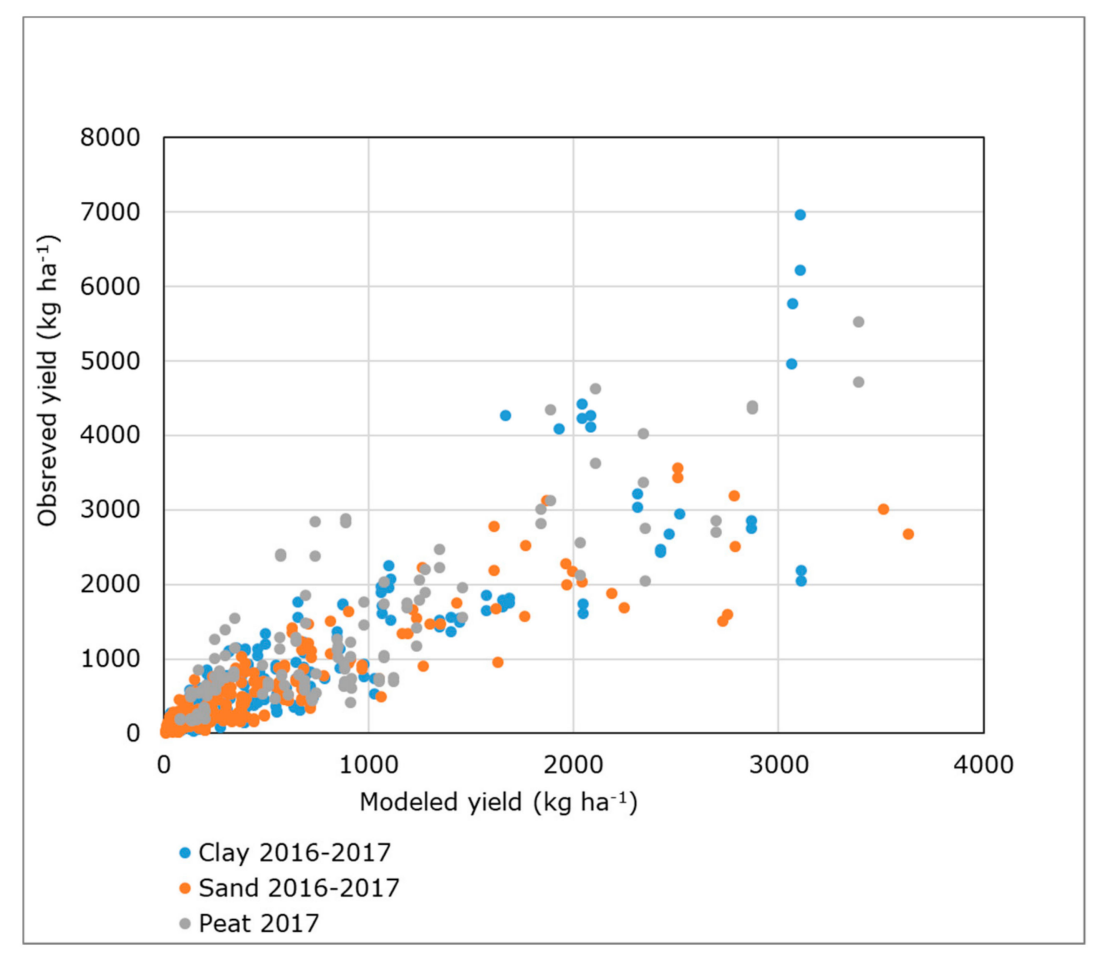

Figure 5. Relationship between predicted and observed grass dry matter (DM) yields on cutting trials. Adapted from Reference [35]. 


\subsubsection{Grass Supply}

In this component, an existing feed wedge tool was adapted to suit the specific needs of Dutch grassland management. Unlike existing feed wedges, the adapted feed wedge allows variation in the size of the grazing platform. Therefore, farmers are able to decide which paddocks are to be used for grazing or fodder production. Paddocks planned to be used for fodder production are moved from the feed wedge to a cutting window, where information is provided to determine the best moment for cutting. The adapted feed wedge was tested by 10 dairy farmers and advisors between April and July 2017. Half of them were familiar with estimating DM yields and the use of a feed wedge, while the other half were not. During the test period, participants provided weekly feedback. Eventually, only the experienced user group applied the adapted feed wedge weekly in their grassland management. The participants found that user-friendliness could be improved, especially in relation to input of data. The default expected grass growth of the feed wedge was highly appreciated since it clarified the effect of time on grass availability for cutting and grazing.

\subsubsection{Grass Intake}

The grazing system experiments at the Dairy Campus (clay soil) and Zegveld (peat soil) showed that it was possible to achieve an average fresh grass intake of 6 to $7 \mathrm{~kg} \mathrm{DM} \cdot \mathrm{cow}^{-1} \cdot$ day $^{-1}$ at a stocking rate of 7.5 cows $\cdot \mathrm{ha}^{-1}$ on the available grazing area (Table 1 ). At both locations, the grazing system had no effect on fresh grass intake and milk production. The grass silage yield and total grass production were higher for strip grazing than for compartmented continuous grazing at the Dairy Campus, and also higher for strip grazing than for kurzrasen at Zegveld. At Dairy Campus and Zegveld, approximately $70 \%$ and $90 \%$ of the total grass production was utilized by grazing, respectively.

Table 1. System performance at a stocking density of 7.5 cows $\cdot \mathrm{ha}^{-1}$, averaged over 2016 and 2017, for two locations. SG = strip grazing; $\mathrm{CCG}=$ compartmented continuous grazing; $\mathrm{KR}=$ kurzrasen; $\mathrm{DM}=$ dry matter. Data from References [33,37].

\begin{tabular}{|c|c|c|c|c|}
\hline & \multicolumn{2}{|c|}{ Dairy Campus } & \multicolumn{2}{|c|}{ Zegveld } \\
\hline & SG & CCG & SG & $\mathbf{K R}$ \\
\hline Nitrogen input $\left(\mathrm{kg} \cdot \mathrm{ha}^{-1}\right)$ & 305 & 324 & 142 & 142 \\
\hline Grazing season (days) & 174 & 171 & 177 & 186 \\
\hline Pasture time $\left(\mathrm{h} \cdot \mathrm{day}^{-1}\right)$ & 7.6 & 7.4 & 11.9 & 13.0 \\
\hline Grass on offer $(\mathrm{cm})$ & 9.5 & 7.4 & 11.0 & 4.2 \\
\hline Residual sward height $(\mathrm{cm})$ & 5.6 & 6.3 & 6.1 & 4.2 \\
\hline Grass intake $\left(\mathrm{kg} \mathrm{DM} \cdot \mathrm{cow}^{-1} \cdot\right.$ day $\left.^{-1}\right)$ & 5.9 & 6.3 & 6.8 & 6.9 \\
\hline Grass silage intake $\left(\mathrm{kg} \mathrm{DM} \cdot \mathrm{cow}^{-1} \cdot \mathrm{day}^{-1}\right)$ & 1.4 & 0.8 & 3.5 & 3.0 \\
\hline Maize silage intake $\left(\mathrm{kg} \mathrm{DM} \cdot \mathrm{cow}^{-1} \cdot\right.$ day $\left.^{-1}\right)$ & 6.4 & 6.7 & 0.0 & 0.0 \\
\hline Concentrates intake $\left(\mathrm{kg} \mathrm{DM} \cdot \mathrm{cow}^{-1} \cdot\right.$.ay $\left.^{-1}\right)$ & 5.5 & 5.5 & 6.9 & 6.9 \\
\hline Milk production $\left(\mathrm{kg}\right.$ FPCM ${ }^{*} \cdot \mathrm{cow}^{-1} \cdot$ day $\left.^{-1}\right)$ & 27.4 & 27.8 & 22.6 & 22.3 \\
\hline Silage yield $\left(\mathrm{kg} \mathrm{DM} \cdot \mathrm{ha}^{-1}\right)$ & 3.8 & 2.4 & 1.5 & 0.4 \\
\hline
\end{tabular}

${ }^{*}$ Fat and Protein Corrected Milk (4\% Fat and 3.32\% Protein).

\subsubsection{Feed Supplementation}

The results of the detailed grass intake measurements with alkane markers did not provide evidence that cows were motivated to increase their grass intake by feeding them low protein supplements (Figure 6). Grass intake, total intake, and milk production varied between seasons and years, due to variations in cow lactation stage and the seasonal effects of grass supply and composition. Cows on the low protein treatments had larger refusals of maize silage than cows receiving high protein levels. This suggests that cows indeed seem to balance their rumen degradable protein intake, although, in this study, not through a higher intake of grass but due to a reduction of the voluntary intake of maize silage. Because the cows were supplemented with fixed amounts of maize silage, it is 
not possible to draw firm statistically substantiated conclusions. In 2016, supplementation with low rumen degradable protein concentrates resulted in a reduced milk and milk constituent yield.

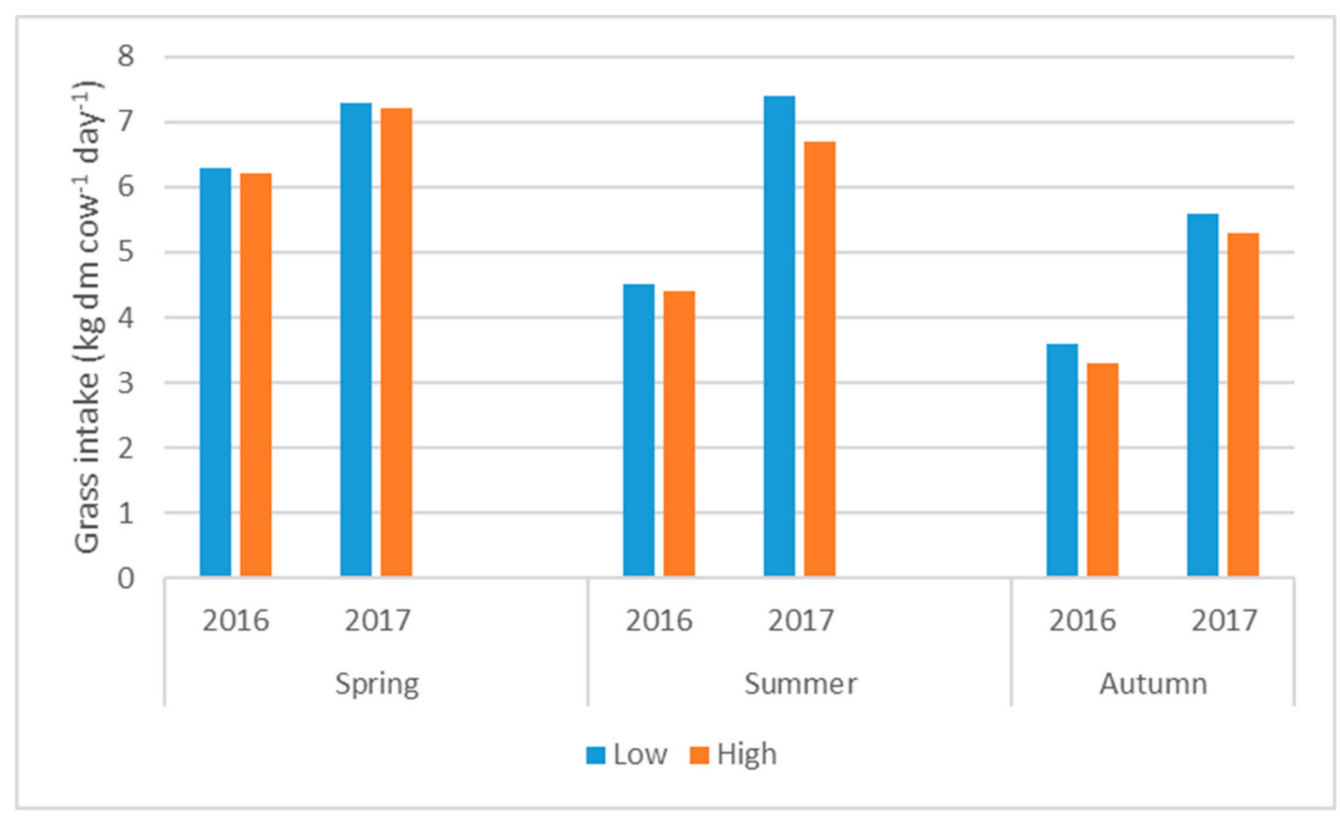

Figure 6. Average grass intake $\left(\mathrm{kg} \mathrm{DM} \cdot \mathrm{cow}^{-1} \cdot \mathrm{day}^{-1}\right)$ at low and high levels of rumen degradable protein balance [38].

\subsubsection{Cow Behavior}

The grass intake data of the alkane measurements were used to develop and calibrate a predictive model of daily grass intake using, amongst others, cow sensor data. We started with a set of more than 30 potential predictors, including (i) animal data on cow weight, milk production, lactation number, lactation stage, and cow activity (using sensor data on eating, ruminating, and walking time and on number of steps), (ii) grassland data on sward height, grass area on offer, and grass quality, and (iii) supplemental feeding data on concentrate and silage intake and quality. All models were evaluated by their root-mean-square error prediction (RMSEP). The best-performing model included 11 predictors. However, the data needed to run this model were not considered to be easily available on a commercial farm. Therefore, an optimal model was established that included five predictors: eating time, number of steps, milk production, lactation number, and lactation stage (Figure 7). The optimal model achieved an RMSEP of $2.1 \mathrm{~kg}$ DM.cow ${ }^{-1} \cdot$ day $^{-1}$ for individual animals, and an RMSEP of $0.6 \mathrm{~kg} \mathrm{DM} \cdot \mathrm{cow}^{-1} \cdot \mathrm{day}^{-1}$ for a herd of 15 animals. These results demonstrate that cow behavioral data can help to reliably estimate grass intake at pasture.

\subsection{Evaluation}

The innovations were evaluated by stakeholders on effectivity, farmers' needs, innovative value, practicality, and implementation potential (Table 2). The evaluation of effectivity was mainly based on the outcomes of the research activities, while all other criteria were evaluated by input from stakeholders. Low protein supplementation to increase grass intake was the only innovation that did not prove to be effective. For all other innovations, there was confidence in the effectiveness, although the type of evidence was difficult to compare between innovations. It is evident that, in order to enter the research phase, all six innovations addressed farmers' needs and had innovative value to some extent. Nevertheless, during the stakeholder meetings, it became clear that grass growth predictions and grass intake (estimation) stood out in farmers' preferences and innovative value. Stakeholder views on applicability and implementation potential were relatively diffuse, compared to the other 
criteria. Therefore, these criteria did not result in very clear guidance. Grass growth prediction and intake estimates with cow sensors were selected for the next phase.
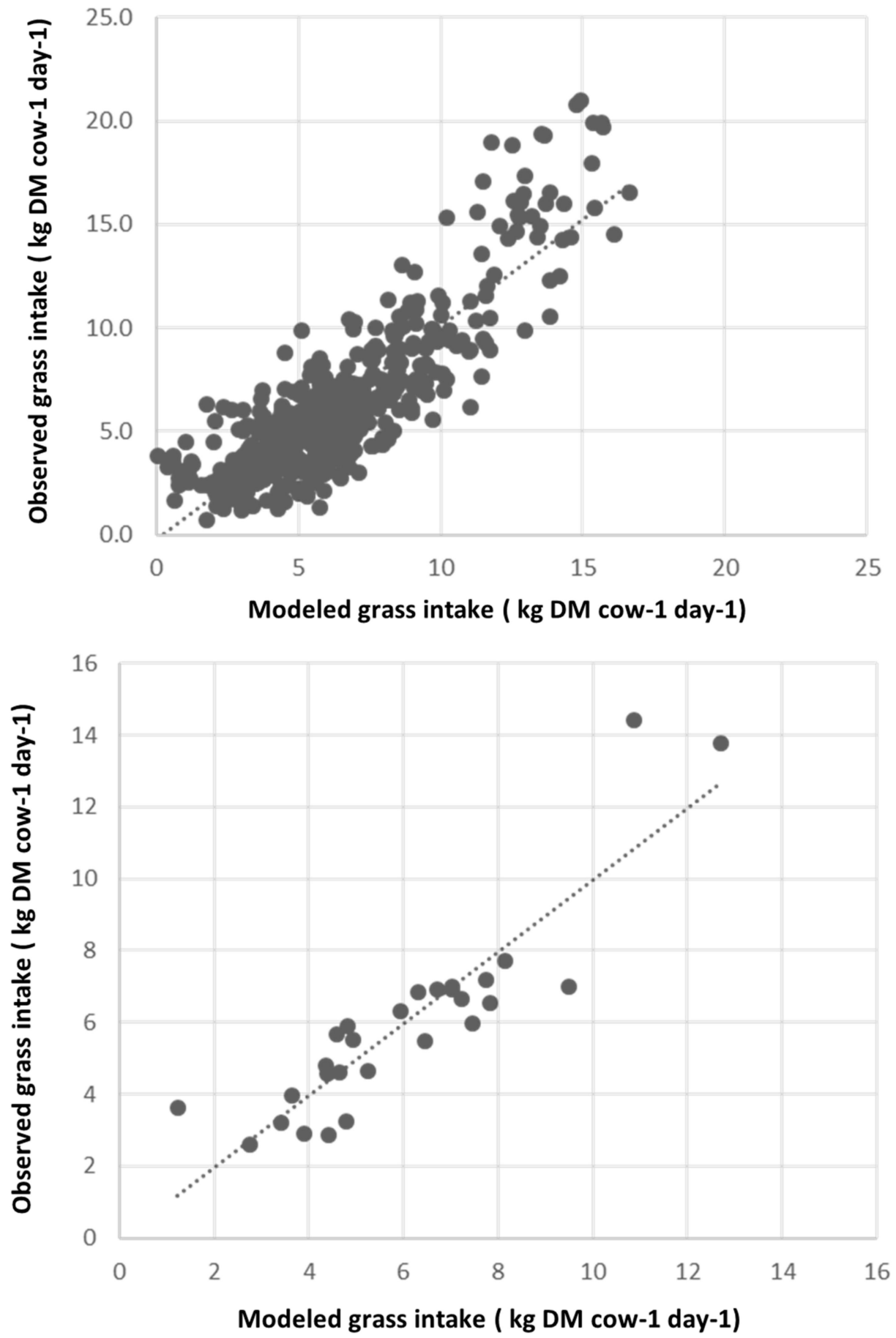

Figure 7. Relationships between observed fresh grass intake and predicted intake for individual animals (above) and herds (below). Adapted data from References [38,39]. 
Table 2. Summary of evaluation results for the six innovations researched in the first phase of Amazing Grazing.

\begin{tabular}{|c|c|c|c|c|c|c|}
\hline Component & Innovation & 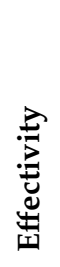 & 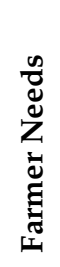 & 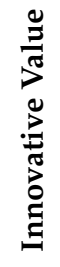 & $\begin{array}{l}\stackrel{2}{:=} \\
\frac{0}{0} \\
\frac{0}{0} \\
\frac{2}{2} \\
\frac{2}{4}\end{array}$ & 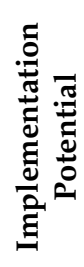 \\
\hline Soil & Kurzrasen to improve soil bearing capacity & $0 /+$ & $0 /+$ & + & 0 & $0 /-$ \\
\hline Grass growth & Short-term grass growth prediction & + & + & + & 0 & + \\
\hline Grass Supply & Cutting window in feed wedge & $0 /+$ & $0 /+$ & 0 & $0 /+$ & $0 /+$ \\
\hline Grass intake & Meaningful intake at high stocking density & + & + & $0 /+$ & $0 /+$ & 0 \\
\hline Supplementation & Low protein supplements to increase grass intake & - & 0 & + & $0 /-$ & $0 /-$ \\
\hline Cow behavior & Cow sensors to estimate grass intake & + & + & + & 0 & $0 /+$ \\
\hline
\end{tabular}

\subsection{Prototyping}

Following the second convergence step, the selected innovations were elaborated into design concepts and when possible in working prototypes.

\subsubsection{Short-Term Grass Growth Prediction}

The cutting experiments in the research phase showed that DM yields could be predicted with reasonable accuracy, which is the main premise for a suitable prototype. In addition, the grass growth prediction requires a five-day weather forecast, which is freely available. An important additional requirement, brought in by the stakeholders, is the suitability for grazed grasslands. This adds considerable complexity, as modeling regrowth from a heterogeneous grazed sward requires information on the pattern of rejected areas and the sward state in and around those areas.

The main categories of input variables for grass growth prediction are grassland management (last grazing or cutting date, fertilizer and manure input), soil type (soil nitrogen supply, texture, rooting depth), and the five-day weather forecast (precipitation, temperature). These variables allow the grass growth model and a coupled soil moisture model to calculate daily grass growth. The concept is yet to evolved into a working prototype. In 2018, a semi-automated approach was successfully applied at the Dairy Campus that predicted grass growth on grazed swards [35,37]. A web-based interface will be developed that collects daily inputs from farmers and meteorology providers, executes the model runs, and communicates the output to the farmer.

\subsubsection{Daily Fresh Grass Intake Tracking}

The concept of daily fresh grass intake tracking aims to provide farmers, at the end of the day, with an estimate of fresh grass intake at pasture. It was designed around the simplified model, requiring five input variables: eating time and number of steps from neck and leg sensors, daily milk production, days in milk, and age of the animal. This concept was elaborated into a working prototype that was tested at the Dairy Campus during the grazing season of 2018. The pilot showed that it was possible to collect and process the required data, run the model, and export and communicate the output to the farm manager (Figure 8). The outcomes were not validated against grass intake measurements, but showed levels and day-to-day variation that could be correlated to the variation in intake of supplements like maize silage. 


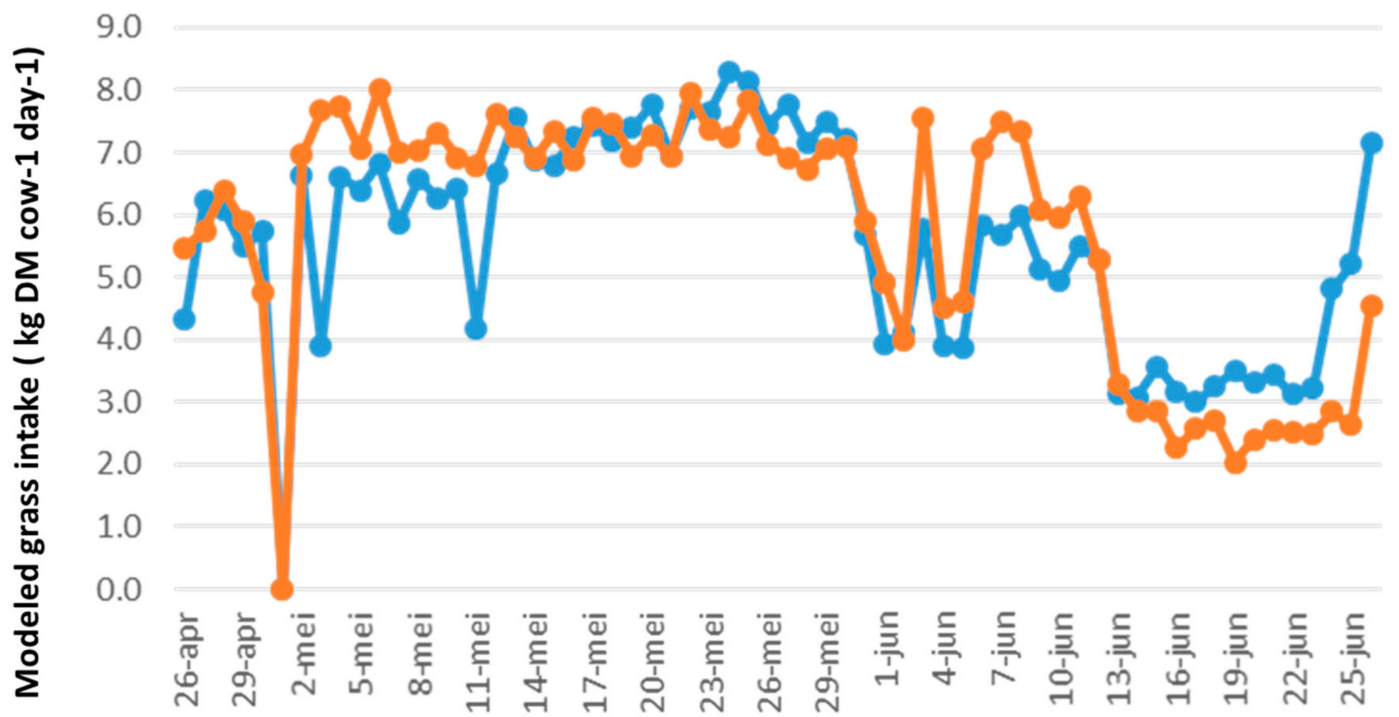

Figure 8. Predicted fresh grass intake at the Dairy Campus 2018 pilot for strip grazing (blue) and continuous grazing (orange). Data from References [37,39].

\section{Discussion}

\subsection{Public-Private Partnership and Innovation}

A review of four cases of public-private partnerships in Dutch agriculture concluded that public-private partnerships are especially suitable as systemic policy instruments in the early phases of the development of an emerging technical innovation system, also the so-called pre-competitive research phase [29]. They argued that public-private partnerships stimulate those functions, i.e., knowledge development, network building, diffusion, and guidance of search, that are important in the early development phases. The reviewed public-private partnerships were less capable of stimulating the final market development and consumer demand, because competition between stakeholders becomes more of an issue. To some extent, this also applies to Amazing Grazing, although there was no specific objective to develop market-ready innovations at the start. The concept of daily grass intake tracking was developed into a working prototype as the private partner that supplied the neck and leg sensors is dedicated to exploring market introduction. For the concept of grass growth prediction, the potential private partner did not yet see a market perspective, partly due to a perceived lack of demand in grassland management decision support systems.

\subsection{Contribution to Grazing Practices}

The objective of this innovation network was to develop and stimulate uptake of technological innovations and management measures that increase uptake of efficient grazing practices. For each of the six components in the Amazing Grazing framework, relevant research questions were addressed, and findings, tools, and model prototypes were communicated to the different stakeholders. Furthermore, we demonstrated that meaningful grazing and fresh grass intake, around 6 to $7 \mathrm{~kg} \mathrm{DM} \cdot \mathrm{cow}^{-1} \cdot \mathrm{day}^{-1}$, is possible in intensive dairy systems with high stocking rates and high levels of supplementary feeding. On the grazing area, more than $70 \%$ of the grass production was utilized by grazing. In farming practice, usually less than $50 \%$ of the grass production is utilized by grazing. In addition to generating new knowledge on grazing, the project did succeed in designing concepts for two specific innovations, i.e., weekly grass growth predictions and daily fresh grass intake tracking. The latter innovation was translated into a working prototype. However, at this stage, it is hard to evaluate whether the concepts will eventually be taken up, and, more importantly, whether they will stimulate grazing practices, and contribute to preventing a further decline of grazing practices. 
Currently, the proportion of farms practicing grazing is increasing again. However, it is evident that this cannot be attributed to Amazing Grazing.

Pasture measurement tools and decision-support systems for grazing management provide opportunities to optimize pasture and grazing management [40]. To our knowledge, there are no examples of on-farm implementation of daily grass intake tracking, in the Netherlands or abroad, although the use of behavioral data to predict intake is receiving increasing interest [41-44]. The use of grass growth prediction models in decision support systems was studied more widely, especially in more grazing-oriented countries like Ireland [45,46] and New Zealand [47,48].

For both innovations of Amazing Grazing, there is clear interest by farmers, as two farm pilots are currently running with five participating farms each. The objectives of the pilot are (i) combining hardware and software for data collection and processing, (ii) generating daily output on fresh grass intake or predicted grass growth, (iii) collecting user experiences, and (iv) evaluation of output.

It has to be realized that the uptake of grazing depends on more than just technical innovations. Among the drivers listed in the introduction, the outcomes of Amazing Grazing mainly help to alleviate issues around grazing knowledge and management skills of farmers. The outcomes may also help to overcome the problems associated with implementing grazing on larger farms. In addition to knowledge development, other initiatives are important to stimulate grazing such as milk price incentives, Common Agricultural Policy (CAP) reform, and direct grazing regulations [1]. A review on innovations in grasslands [49] presented some explanation as to why there is a relative low innovation rate in grassland technology, such as complexity and diversity of grassland-based systems, large time lag before benefits of innovations become visible, contradictory effects on sustainability, and limited interaction between farmers and research.

\section{Conclusions}

The use of a public-private partnership to develop usable innovations that encourage grazing practices proved to be a good approach to develop a shared vision among stakeholders. It provided a basis to work together toward innovative practices and disseminate the outcomes to the foreseen users.

In addition to generating new knowledge on grazing, the approach of Amazing Grazing succeeded in designing concepts for two specific innovations, i.e., weekly grass growth predictions and daily fresh grass intake tracking. The latter innovation was translated into a working prototype. We established that meaningful grazing and fresh grass intake is possible in intensive dairy systems with high stocking rates and high levels of supplementary feeding. These findings help to alleviate some of the bottlenecks connected to increasing farm sizes and stocking rates on the grazing area, as well as lack of knowledge.

Author Contributions: Methodology R.S., B.P, N.H., G.H., R.Z., I.H., K.v.R., M.S., C.K., I.v.D., A.v.d.P.-v.D. supervision R.S., B.P., N.v.E., A.v.d.P.-v.D.; visualization R.S., writing-original draft R.S.; Funding acquisition B.P., N.v.E., project administration B.P.; Formal analysis, N.H., G.H., R.Z., I.H., I.H., K.v.R., M.S., C.K., L.S.; software G.H., J.v.d.W.; data curation J.v.d.W.; writing-review and editing B.P., N.H., G.H., R.Z., I.H., K.v.R., M.S., C.K., J.v.d.W., L.S., N.v.E., I.v.D., A.v.d.P.-v.D.

Funding: We received financial support from ZuivelNL, LTO, NZO, and the Dutch Ministry of Agriculture, Nature, and Food Quality, as well as the Province of Friesland.

Acknowledgments: We thank the participating stakeholders and participating dairy farmers for their input, the staff at the Dairy Campus and Zegveld for the execution of the experimental work, René Schepers for his creative guidance from conception to implementation, and Marry van den Top for all communication activities. We also acknowledge the suggestions for improving the manuscript that we received from two anonymous reviewers.

Conflicts of Interest: The authors declare no conflict of interest. Representatives of the funders participated as stakeholders, and thus had a role in the design of the study. The funders had no role in the collection, analyses, or interpretation of data; in the writing of the manuscript, or in the decision to publish the results. 


\section{References}

1. Reijs, J.W.; Daatselaar, C.H.G.; Helming, J.F.M.; Jager, J.H.; Beldman, A.C.G. Grazing Dairy Cows in North-West Europe: Economic Farm Performance and Future Developments with Emphasis on the Dutch Situation; Report 9789086156375; LEI Wageningen UR: The Hague, The Netherlands, 2013.

2. Van Den Pol-Van Dasselaar, A.; De Vliegher, A.; Hennessy, D.; Isselstein, J.; Peyraud, J.L. The Future of Grazing: Proceedings of the Third Meeting of the EGF Working Group "Grazing"; Livestock Research Report 906; Wageningen UR: Wageningen, The Hague, The Netherlands, 2015; p. 38.

3. Van Den Pol-Van Dasselaar, A.; De Vliegher, A.; Hennessy, D.; Isselstein, J. Grazing in a High-Tech World: Proceedings 5th Meeting EGF Working Group "Grazing" in Trondheim; Livestock Research Report 1079; Wageningen UR: Wageningen, The Hague, The Netherlands, 2017.

4. CBS. Weidegang Van Melkvee 1997-2015. Available online: https://opendata.cbs.nl/statline/\#/CBS/nl/dataset/ 70736ned/table?fromstatweb (accessed on 1 March 2019).

5. CBS. Weidegang Van Melkvee; GVE-Klasse, Regio. Available online: https://opendata.cbs.nl/statline/\#/CBS/ nl/dataset/83953NED/table (accessed on 1 March 2019).

6. Van Den Pol-Van Dasselaar, A.; Aarts, H.; De Caesteker, E.; De Vliegher, A.; Elgersma, A.; Reheul, D.; Reijneveld, J.A.; Vaes, R. Grassland and Forages in High Output Dairy Farming Systems in Flanders and the Netherlands. In Grassland and Forages in High Output Dairy Farming Systems; EGF: Wageningen, The Netherlands, 2015; Volume 20, pp. 3-11.

7. Van Den Pol-Van Dasselaar, A.; De Haan, M.; Philipsen, A.P. Beweiding in Nederland; Livestock Research Report 687; Wageningen UR, Wageningen: The Hague, The Netherlands, 2013.

8. Boogaard, B.K.; Bock, B.B.; Oosting, S.J.; Wiskerke, J.S.C.; Van Der Zijpp, A.J. Social Acceptance of Dairy Farming: The Ambivalence Between the Two Faces of Modernity. J. Agric. Environ. Ethics 2011, 24, $259-282$. [CrossRef]

9. Kuhl, S.; Gauly, S.; Spiller, A. Analysing Public Acceptance of Four Common Husbandry Systems for Dairy Cattle Using a Picture-Based Approach. Livest. Sci. 2019, 220, 196-204. [CrossRef]

10. Leroy, G.; Hoffmann, I.; From, T.; Hiemstra, S.J.; Gandini, G. Perception of Livestock Ecosystem Services in Grazing Areas. Animal 2018, 12, 2627-2638. [CrossRef] [PubMed]

11. Arnott, G.; Ferris, C.P.; Oconnell, N.E. Review: Welfare of Dairy Cows in Continuously Housed and Pasture-Based Production Systems. Animal 2017, 11, 261-273. [CrossRef]

12. Charlton, G.L.; Rutter, S. The Behaviour of Housed Dairy Cattle with and without Pasture Access: A Review. Appl. Anim. Behav. Sci. 2017, 192, 2-9. [CrossRef]

13. Von Keyserlingk, M.A.G.; Cestari, A.A.; Franks, B.; Fregonesi, J.A.; Weary, D.M. Dairy Cows Value Access to Pasture as Highly as Fresh Feed. Sci. Rep. 2017, 7, 44953. [CrossRef]

14. Cameron, L.; Chagunda, M.G.G.; Roberts, D.J.; Lee, M.A. A Comparison of Milk Yields and Methane Production from Three Contrasting High-Yielding Dairy Cattle Feeding Regimes: Cut-And-Carry, Partial Grazing and Total Mixed Ration. Grass Forage Sci. 2018, 73, 789-797. [CrossRef]

15. O’Brien, D.; Shalloo, L.; Patton, J.; Buckley, F.; Grainger, C.; Wallace, M. A Life Cycle Assessment of Seasonal Grass-Based and Confinement Dairy Farms. Agric. Syst. 2012, 107, 33-46. [CrossRef]

16. O'Neill, B.; Deighton, M.; O'Loughlin, B.; Galvin, N.; O’Donovan, M.; Lewis, E.; Deighton, M. The Effects of Supplementing Grazing Dairy Cows with Partial Mixed Ration on Enteric Methane Emissions and Milk Production during Mid to Late Lactation. J. Dairy Sci. 2012, 95, 6582-6590. [CrossRef]

17. Gulati, A.; Galvin, N.; Lewis, E.; Hennessy, D.; O’Donovan, M.; McManus, J.J.; Fenelon, M.A.; Guinee, T.P. Outdoor Grazing of Dairy Cows on Pasture Versus Indoor Feeding on Total Mixed Ration: Effects on Gross Composition and Mineral Content of Milk during Lactation. J. Dairy Sci. 2018, 101, 2710-2723. [CrossRef]

18. O'Callaghan, T.F.; Faulkner, H.; McAuliffe, S.; O'Sullivan, M.G.; Hennessy, D.; Dillon, P.; Kilcawley, K.N.; Stanton, C.; Ross, R.; Ross, R. Quality Characteristics, Chemical Composition, and Sensory Properties of Butter from Cows on Pasture Versus Indoor Feeding Systems. J. Dairy Sci. 2016, 99, 9441-9460. [CrossRef] [PubMed]

19. O'Callaghan, T.F.; Hennessy, D.; McAuliffe, S.; Kilcawley, K.N.; O’Donovan, M.; Dillon, P.; Ross, R.; Stanton, C.; Ross, R. Effect of Pasture Versus Indoor Feeding Systems on Raw Milk Composition and Quality over an Entire Lactation. J. Dairy Sci. 2016, 99, 9424-9440. [CrossRef] [PubMed] 
20. Hartigh, L.J.D. Conjugated Linoleic Acid Effects on Cancer, Obesity, and Atherosclerosis: A Review of Pre-Clinical and Human Trials with Current Perspectives. Nutrients 2019, 11, 370. [CrossRef] [PubMed]

21. Stewart, R.L., Jr.; Silcox, R.E.; Lacy, C.; Hancock, D.W.; Harris, G.H.; Ellis, R.W. Improve grazing management, increase forage use efficiency. Available online: https://www.progressiveforage.com/forage-types/grassesand-grazing/improve-grazing-management-increase-forage-use-efficiency (accessed on 1 June 2019).

22. Van Vuuren, A.M.; Van Den Pol-Van Dasselaar, A. Grazing Systems and Feed Supplementation. In Fresh Herbage for Dairy Cattle: The Key to a Sustainable Food Chain; No. 18; Springer: Berlin, Germany, 2006; pp. 85-101.

23. Peyraud, J.L.; Delagarde, R. Managing Variations in Dairy Cow Nutrient Supply Under Grazing. Animal 2013, 7, 57-67. [CrossRef] [PubMed]

24. Klootwijk, C.W. Keys to Sustainable Grazing: Economic and Environmental Consequences of Grazing Strategies for Dairy Farms. Ph.D. Thesis, Wageningen University, The Hague, The Netherlands, 2019.

25. Van Den Pol-Van Dasselaar, A.; Blokland, P.W.; Gies, T.J.A.; Holshof, G.; De Haan, M.H.A.; Naeff, H.S.D.; Philipsen, A.P. Beweidbare Oppervlakte En Weidegang Op Melkveebedrijven in Nederland; Livestock Research Report 917; Wageningen UR: Wageningen, The Hague, The Netherlands, 2015.

26. Spiertz, J.; Kropff, M.; Kropff, M. Adaptation of Knowledge Systems to Changes in Agriculture and Society: The Case of the Netherlands. NJAS Wagening. J. Life Sci. 2011, 58, 1-10. [CrossRef]

27. Knickel, K.; Brunori, G.; Rand, S.; Proost, J. Towards a Better Conceptual Framework for Innovation Processes in Agriculture and Rural Development: From Linear Models to Systemic Approaches. J. Agric. Educ. Ext. 2009, 15, 131-146. [CrossRef]

28. Turner, J.A.; Klerkx, L.; Rijswijk, K.; Williams, T.; Barnard, T. Systemic Problems Affecting Co-Innovation in the New Zealand Agricultural Innovation System: Identification of Blocking Mechanisms and Underlying Institutional Logics. NJAS Wagening. J. Life Sci. 2016, 76, 99-112. [CrossRef]

29. Hermans, F.; Geerling-Eiff, F.; Potters, J.; Klerkx, L. Public-Private Partnerships as Systemic Agricultural Innovation Policy Instruments-Assessing their Contribution to Innovation System Function Dynamics. NJAS Wagening. J. Life Sci. 2019, 88, 76-95. [CrossRef]

30. Fielke, S.J.; Botha, N.; Reid, J.; Gray, D.; Blackett, P.; Park, N.; Williams, T. Lessons for Co-Innovation in Agricultural Innovation Systems: A multiple Case Study Analysis and a Conceptual Model. J. Agric. Educ. Ext. 2018, 24, 9-27. [CrossRef]

31. Van Duinkerken, G.; Philipsen, A.; Van Den Pol, A. Gras En Weidegang, Onderzoeksprogramma $2014-2019$. Available online: https://www.wur.nl/nl/artikel/Gras-en-weidegang-Onderzoeksprogramma-2014--2019.htm (accessed on 1 March 2019).

32. Koerkamp, P.G.; Bos, A. Designing Complex and Sustainable Agricultural Production Systems: An Integrated and Reflexive Approach for the Case of Table Egg Production in the Netherlands. NJAS Wagening. J. Life Sci. 2008, 55, 113-138. [CrossRef]

33. Hoekstra, N.H.; Holshof, G.; Schils, R.L.M.; Philipsen, A.P.; Van Reenen, K.; Van Houwelingen, K.M.; Van Eekeren, N. The effect of kurzrasen and strip-grazing on grassland performance and soil quality of a peat meadow. Sustainability. in press.

34. Holshof, G.; Van Den Pol-Van Dasselaar, A. Modelling DM Growth of Multi-Species Grassland Plots in the Netherlands. In Proceedings of the 25th EGF General Meeting on EGF at 50; The Future of European Grasslands: Wageningen, The Netherlands, 2014; Volume 19, pp. 725-727.

35. Hoving, I.; Van Riel, J.; Holshof, G.; Plomp, M.; Agricola, S.; Van Boheemen, K.; Roerink, G. Schatten Van Grasopbrengst Op Basis Van Spectrale Reflectie, Grashoogte En Modellering; Livestock Research Report 1200; Wageningen UR: Wageningen The Netherlands, 2019.

36. Stienezen, M.; Philipsen, A.; Schils, R.; Van Den Pol-Van Dasselaar, A. Amazing Grazing: Feed Wedge and Cutting Window for Grazing Systems with High Levels of Supplementation. In Sustainable Meat and Milk Production from Grasslands; No. 23; EGF: Wageningen, The Netherlands, 2018; p. 819.

37. Holshof, G.; Zom, R.; Schils, R.; Philipsen, A.; Van Den Pol-Van Dasselaar, A.; Klootwijk, C. Amazing Grazing; Substantial Fresh Grass Intake in Restricted Grazing Systems with High Stocking Rates. In Sustainable Meat and Milk Production from Grasslands; No. 23; EGF: Wageningen, The Netherlands, 2018; pp. 234-237.

38. Zom, R.; Van Berkel, I.; Oegema, M.; Holshof, G. Can We Motivate Dairy Cows to Increase their Grass Intake by Feeding Low Protein Supplements? In Sustainable Meat and Milk Production from Grasslands. 
In Sustainable Meat and Milk Production from Grasslands; No. 23; EGF: Wageningen, The Netherlands, 2018; pp. 407-409.

39. Zom, R.; Van Der Werf, J.; Timmer, B.; Hoeksma, D.; Van Reenen, C. Grazing Behaviour in Dairy Cows as a Predictor of Grass Intake. In Proceedings of the Abstracts of the 67th Annual Meeting of the European Association for Animal Production, Belfast, UK, 29 August-1 September 2016; p. 498.

40. Eastwood, C.R.; Dela Rue, B.T.; Gray, D.I. Using a Network of Practice Approach to Match Grazing Decision-Support System Design with Farmer Practice. Anim. Prod. Sci. 2016, 57, 1536-1542. [CrossRef]

41. Halachmi, I.; Meir, Y.B.; Miron, J.; Maltz, E. Feeding Behavior Improves Prediction of Dairy Cow Voluntary Feed Intake but Cannot Serve as the Sole Indicator. Animal 2016, 10, 1501-1506. [CrossRef] [PubMed]

42. Rombach, M.; Munger, A.; Niederhauser, J.; Sudekum, K.H.; Schori, F. Evaluation and Validation of an Automatic Jaw Movement Recorder (RumiWatch) for Ingestive and Rumination Behaviors of Dairy Cows During Grazing and Supplementation. J. Dairy Sci. 2018, 101, 2463-2475. [CrossRef] [PubMed]

43. Rombach, M.; Sudekum, K.H.; Munger, A.; Schori, F. Herbage Dry Matter Intake Estimation of Grazing Dairy Cows Based on Animal, Behavioral, Environmental, and Feed Variables. J. Dairy Sci. 2019, 102, 2985-2999. [CrossRef] [PubMed]

44. Werner, J.; Viel, J.; Niederhauser, J.; O’Leary, N.; Umstatter, C.; O’Brien, B. Validation of New Algorithms for the RumiWatch Noseband Sensor to Detect Grazing Behaviour of Dairy Cows. In Sustainable Meat and Milk Production from Grasslands; No. 23; EGF: Wageningen, The Netherlands, 2018; pp. 917-919.

45. Barrett, P.; Laidlaw, A.; Mayne, C. GrazeGro: A European Herbage Growth Model to Predict Pasture Production in Perennial Ryegrass Swards for Decision Support. Eur. J. Agron. 2005, 23, 37-56. [CrossRef]

46. Hanrahan, L.; Geoghegan, A.; O’Donovan, M.; Griffith, V.; Ruelle, E.; Wallace, M.; Shalloo, L. PastureBase Ireland: A Grassland Decision Support System and National Database. Comput. Electron. Agric. 2017, 136, 193-201. [CrossRef]

47. Romera, A.; Beukes, P.; Clark, C.; Clark, D.; Levy, H.; Tait, A. Use of a Pasture Growth Model to Estimate Herbage Mass at a Paddock Scale and Assist Management on Dairy Farms. Comput. Electron. Agric. 2010, 74, 66-72. [CrossRef]

48. Romera, A.; Beukes, P.; Clark, D.; Clark, C.; Tait, A. Pasture Growth Model to Assist Management on Dairy Farms: Testing the Concept with Farmers. Grassl. Sci. 2013, 59, 20-29. [CrossRef]

49. Krause, A.; Becker, T.; Feindt, P.H.; Huyghe, C.; O’Donovan, M.; Peeters, A.; Van Den Pol-Van Dasselaar, A. Towards Sustainable European Grassland Farming with Inno4Grass: An Infrastructure for Innovation and Knowledge Sharing. In Sustainable Meat and Milk Production from Grasslands; No. 23; EGF: Wageningen, The Netherlands, 2018; pp. 925-936. 